\title{
Antioxidant properties, quantification and stability of betalains from pitaya (Hylocereus undatus) peel
}

\author{
Propriedades antioxidantes, quantificação e estabilidade \\ das betalaínas da casca da pitaya (Hylocereus undatus)
}

\section{Fernanda Robert de Mello ${ }^{\text {I }}$ Claudia Bernardo ${ }^{\text {II }}$ Caroline Odebrecht Dias ${ }^{\text {II }}$ Luciano Gonzaga $^{\text {II }}$ Edna Regina Amante ${ }^{I I}$ Roseane Fett ${ }^{I I}$ Lys Mary Bileski Candido ${ }^{I I I}$}

\section{ABSTRACT}

Pitaya peel can be used as a raw material for betalains extraction. The aim of this research was to quantify phenolic compounds, antioxidant activity and betalains on pitaya peel. Furthermore, evaluate the betalains stability against various $\mathrm{pH}$ conditions and exposure time of heating. The results showed that pitaya peel contains phenolic compounds and presented antioxidant activity. Moreover it showed high concentration of betalains (101.04mg equivalent to betanin. $100 \mathrm{~g}^{-1}$ ) which were stable over a wide pH range (3.2 - 7.0) and were resistant to heating $\left(100^{\circ} \mathrm{C}\right)$ up to 10 minutes at $\mathrm{pH}$ range from 3.7 to 5.5 Therefore, pitaya peel is a promising source of betalains which can be applied as a natural colorant for food.

Key words: betalains, antioxidant activity, colorant, phenolic compounds.

RESUMO

A casca da pitaya pode ser utilizada como matéria prima para a extração de betalaínas. O objetivo deste trabalho foi quantificar os compostos fenólicos, atividade antioxidante e as betalainas presentes na casca da pitaya. Além disso, foi avaliada a estabilidade das betalainas em diferentes condições de pH e tempo de exposição ao aquecimento. Os resultados mostraram que a casca da pitaya contém compostos fenólicos e apresenta atividade antioxidante. Além disso, a casca da pitaya apresenta alta concentração de betalaínas (101,04mg equivalente a betanina. $\left.100 \mathrm{~g}^{-1}\right)$ as quais apresentaram-se estáveis em uma ampla faixa de pH $(3,2-7,0)$ e resistentes ao aquecimento $\left(100^{\circ} \mathrm{C}\right)$ por até 10 minutos em uma faixa de $\mathrm{pH}$ de 3,7 a 5,5. Portanto, a casca da pitaya é uma fonte promissora de betalaínas as quais podem ser aplicadas como corante natural para alimentos.

Palavras-chave: betalainas, atividade antioxidante, corante, compostos fenólicos.

\section{INTRODUCTION}

Pitaya, belongs to Cactacea family, and is a native fruit from Mexico and Central and South America (MIZRAHI et al., 1997). There are many species of the fruit, however the Hylocereus undatus is the best known and cultivated. Pitaya peel is considered a residue from the consumption and processing of the fruit (JAMILAH et al., 2011) and it is usually discarded. However, this residue can be used as raw material for the extraction of pigments, due to the presence of betalains which present attractive and stable color (LI-CHEN et al., 2006).

Betalains are a group of nitrogen pigments, which are water soluble and provide attractive coloration for some groups of flowers and fruits. There are two subgroups, the betacyanin red-violet and betaxantins yellow-orange (MOßHAMMER, et al., 2005; HERBACH et al., 2006a). The betalains received less scientific attention than other classes of natural pigments (chlorophylls, carotenoids and anthocyanins) due to their restricted occurrence (STINTZING et al., 2005).

Currently beet (Beta vulgaris) is the main source of commercial extraction of betalains. However, beets contain substances as geosmin and pyrazines which are responsible for the off flavor (ground) in this culture (STINTZING \& CARLE, 2004). The betalains extracted from pitaya, unlike

\footnotetext{
'Setor de Tecnologia, Universidade Federal do Paraná (UFPR), CP 19011, 81531-980, Curitiba, PR, Brasil. E-mail: nandarobert@gmail.com. Corresponding author.

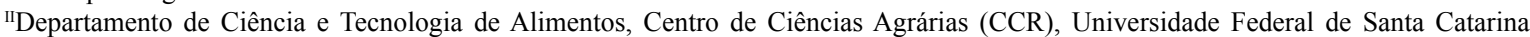
(UFSC), Florianópolis, SC, Brasil.

IIIDepartamento de Química e Biologia, Universidade Tecnológica Federal do Paraná (UTFPR), Curitiba, PR, Brasil.
} 
the red beet, can be used in foods without flavor, and it covers a wide spectrum of color from yelloworange (Opuntia) to red-violet (Hylocereus) (MOBHAMMER et al., 2005).

The aim of this research was to quantify phenolic compounds, antioxidant activity and betalains on pitaya (Hylocereus undatus) peel. Furthermore, evaluate the betalains stability against various $\mathrm{pH}$ conditions and exposure time of heating.

\section{MATERIALS AND METHODS}

Samples (thirty units) of pitaya (Hylocereus undatus) were harvested at Embrapa Brasília-DF, Brazil, in 2011 January. The fruits were stored in a cold chamber $\left(6^{\circ} \mathrm{C}\right)$ at the laboratory of fruits and vegetables at the Federal University of Santa Catarina.

The reagents used were all of analytical grade. Reagents: Folin-Ciocalteu, 2,4,6-tris-(2pyridyl) -1,3,5-triazine (TPTZ), 2,2-diphenyl-1picrylhydrazyl (DPPH), Trolox(6-hydroxy-2,5,7,8tetrametilchroman-2-carboxylic acid) were obtained from Sigma Aldrich (Santa Ana, USA). Acetone was obtained from Vetec (Rio de Janeiro, Brazil) and the water used was filtered through deionization system (deionizer Milli-Q, Millipore, Bedford, USA).

Samples preparation: the fruits were washed and the pitaya peel was manually separated. Part of the pitaya peel samples was used in natura to total phenolic compounds and antioxidant analysis. The other part was completely dehydrated in a common oven (DeLeo, DLS04) at $45^{\circ} \mathrm{C}$ for about 12 hours, until constant weight, grinded (Quimis, Q298A21), packaged in polyethylene bags and stored in a freezer $\left(-18^{\circ} \mathrm{C}\right)$. The moisture of the samples was determined previously each analysis, to express results at dry basis weight.

Extracts preparation: the extracts were obtained from pitaya peel of the three fruits, retired from the lot of thirty fruits. Pitaya peels were grounded in a food processor (RI Philips 1342). The crushed sample (5g) was taken for extraction at room temperature, using $200 \mathrm{~mL}$ of acetone $(80 \%)$ in an ultrasound (Unique, USC1400) for $15 \mathrm{~min}$. After that, it was filtered through Whatman $\mathrm{n}^{\mathrm{0}} 1$ filter paper. The filtrate was then evaporated in a rotary evaporator and frozen at $-18^{\circ} \mathrm{C}$.

Determination of total phenolic content: the content of phenolic compounds was determined from in natura pitaya peel samples according to Folin-Ciocalteu (ROSSI \& SINGLETON, 1965) that determines total phenols (and other oxidized substances), producing a blue color by reducing yellow heteropoly phosphomolybdate-tungstate anions (WU et al., 2006).

Determination of antioxidant activity: the determination of antioxidant activity was performed from in natura pitaya peel samples, using the following methods: FRAP method - the evaluation of reducer potential of iron (FRAP) was determined according to the methodology described by BENZIE $\&$ STRAIN (1996) and DPPH method - the reduction of the stable radical DPPH was determined according to the methodology described by BRAND-WILLAMS et al. (1995), with modifications by KIM et al. (2002).

Quantification of betalains: a sample of dried pitaya peel $(1 \mathrm{~g})$ was diluted with distilled water, and transferred to a flask, where the volume was completed to $100 \mathrm{~mL}$, filtered with a vacuum pump with filter paper Whatmann ${ }^{\circ} 1$. The filtrate was then used to spectrophotometer (HITACHI U-1800) analysis and the readings at $536 \mathrm{~nm}$ were performed in triplicate. Quantification of betalains was calculated according to Beer-Lambert-Bougue Law, modified by TANG \& NORZIAH (2007).

Stability of betalains: the stability of betalains present in the pitaya peel was evaluated by exposing the extracts of betalains at various $\mathrm{pH}$ conditions $(2.4,3.2,3.7,4.2,4.5 ; 5,5.5,6,6.5,7,7.5$, $8)$ and exposure times $(0,5,10,20,30,40,50,60,70$, 80 to $90 \mathrm{~min})$ at temperature of $100^{\circ} \mathrm{C}$. The extracts were prepared from dehydrated samples $(1 \mathrm{~g})$, diluted in buffer solution of $\mathrm{Na}_{2} \mathrm{HPO}_{4}(0.2 \mathrm{M})$ and citric acid $(0.1 \mathrm{M})$. The extract was exposed to a temperature of $100{ }^{\circ} \mathrm{C}$, and three samples were taken at time intervals for the analysis at the spectrophotometer (Hitachi, U-1800) scanning absorbance at 280-780nm at a speed of 400nm. min ${ }^{-1}$, and colorimeter (Minolta CR400 Chroma) with illuminant D65 and the CIE L * a $* \mathrm{~b} *$, in triplicate.

\section{RESULTS AND DISCUSSION}

Total phenolic content and antioxidant activity Fresh pitaya peel (moisture of $90.23 \mathrm{~g}$. $\left.100 \mathrm{~g}^{-1}\right)$ presents high level of phenolic content (40.68mg GAE. $100 \mathrm{~g}^{-1}$ ). Content of total phenolic compounds is high, being similar to that found in white grape, blueberry, apple, pear and plum (VAILLANT et al., 2005). Wu et al. (2006) found phenolic total content of $39.7 \pm 5.39 \mathrm{mg}$ of GAE. $100 \mathrm{~g}^{-1}$ in pitaya peel. Although, Choo \& Yong (2001) found higher total phenolic content in the pulp $(28.65 \mathrm{mg}$ GAE. $\left.100 \mathrm{~g}^{-1}\right)$ than in the pulp + peel $\left(20.14 \mathrm{mg}\right.$ GAE. $\left.100 \mathrm{~g}^{-1}\right)$. The levels of phenolic compounds detected in pitaya are considerably high compared with other 
fruits such as banana - $11 \mathrm{mg}$ GAE. $100 \mathrm{~g}^{-1}$, pineapple - $15 \mathrm{mg}$ GAE. $100 \mathrm{~g}^{-1}$, papaya - 26mg GAE. $100 \mathrm{~g}^{-1}$ and low compared with cherry $670 \mathrm{mg}^{\mathrm{GAE}} .100 \mathrm{~g}^{-1}$ and

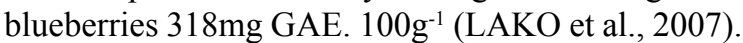

Pitaya peel presented higher antioxidant activity when analyzed by DPPH $(177.14 \mu \mathrm{mol}$ AEAC. $100 \mathrm{~g}^{-1}$ ) than when analyzed by FRAP $\left(109.29 \mu \mathrm{mol}\right.$ AEAC. $\left.100 \mathrm{~g}^{-1}\right)$ method. On the other hand, the fresh pulp of pitaya presents $306.81 \mu \mathrm{mol}$ AEAC. $100 \mathrm{~g}^{-1}$ (MUÑOZ et al., 2002).

ESQUIVEL et al. (2007) investigated the contributions of phenolics to the antioxidant capacity of purple-red pitaya and concluded that betalains were responsible for the major antioxidant capacity of purple pitaya juices while non-betalainic phenolic compounds contributed the least. They observed a positive correlation between total antioxidant activity (Trolox equivalent antioxidant capacity) and total betalain contents $(R 2=0.75)$. The high betalain content of pitaya seems to contribute significantly to this high antioxidant capacity (VAILLANT et al., 2005).

PANTELIDIS et al. (2007) reported the antioxidant activity of some cultivars of gooseberry

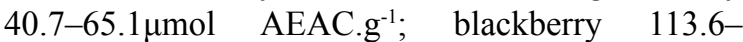
$169.0 \mu \mathrm{mol}$ AEAC. $\mathrm{g}^{-1}$ and raspberry $77.7-145.4 \mu \mathrm{mol}$ AEAC.g ${ }^{-1}$.

Quantification of betalains

Pitaya peel presented $101.04 \mathrm{mg}$ betanin equivalent. $100 \mathrm{~g}^{-1}$ of dry sample. These level was much higher that founded by TANG \& NORZIAH (2007), corresponding to $6.7 \mathrm{mg}$ betanin equivalent. $100 \mathrm{~g}^{-1}$ of fresh pitaya peel, however for Hylocereus polyrhizus species. Figure 1 shows a single peak at about $538 \mathrm{~nm}$. In contrast, beetroot extracts show a second absorption peak at about $480 \mathrm{~nm}$, which is characteristic of yellow betaxanthins (VAILLANT et al., 2005).

Therefore, according to ZHIJIAN \& XIN (2003), pitaya peel can be used as raw material for pigment extraction due to the presence of high betalains concentration.

\section{Stability of betalains}

The betalains of pitaya peel were stable in the $\mathrm{pH}$ range from 3.2 to 7 . The highest degradation was observed at $\mathrm{pH} 2.4$ followed by $\mathrm{pH} 8$, corresponding to extreme acidic and basic analyzed conditions (Figure 1). The stable range of $\mathrm{pH}$ founded is according to STINTZING et al. (2003) and TANG \& NORZIAH (2007), who reported that the color of the pitaya betalains was remarkably stable in the $\mathrm{pH}$ range 3-7.

The maximum absorption was detected at pH 7.0 followed by $\mathrm{pH}$ 4.5. However, CASTELLAR et al. (2003) found the maximum absorption of betalains at $\mathrm{pH}$ from 5.0 to 6.0. Moreover STINTZING et al. (2004) reported that the greatest stability of the color of the betalains from pitaya is at $\mathrm{pH}$ 5.0. The characteristic of stability at acid $\mathrm{pH}$, but greater than 3.0, allows that pitaya betalains can be used as a pigment in low-acid foods (CASTELLAR et al., 2006; VAILLANT et al., 2005).

The betalains have been degraded over time of exposure to a temperature of $100^{\circ} \mathrm{C}$. How greater the exposure, greater is the degradation of the pigment, following a first order reaction kinetics, as reported by HERBACH et al. (2004). The absorption peak at $536 \mathrm{~nm}$ was reduced during the heating time and that after 30 minutes cannot be observed anymore (Figure 1). After 5 minutes of heating, it is possible to observe that there was a shift of absorption maximum $\mathrm{pH}$ from 7.0 to 5.0 , with a reduction of $39.5 \%$ retention of the pigment.

The heating causes degradation of betalains by isomerization, decarboxylation or cleavage resulting in a gradual reduction of red and the appearance of a light brown color (HERBACH et al., 2006b). Cleavage of betanin and isobetanina, which can also be induced by bases (SCHLIEMANN et al., 1999), generates the bright yellow acid betalamic and cyclo-Dopa-5-0-glycoside colorless. HERBACH et al. (2006a) reported that the degradation of betalains is usually accompanied by a marked change in color resulting from the formation of degradation yellow products such as betalamic acid $(424 \mathrm{~nm})$ and betaxantins (460-480nm).

With heat increasing the sample time showed increased of the parameter L* (lightness of the color), decrease of the parameter $a^{*}$ (from red to green) and increase of the parameter $b^{*}$ (from blue to yellow) values, to all $\mathrm{pHs}$ analyzed (Figure 2). This behavior means that with the increasing of heating time the pink color, characteristic of betalains, was degraded to different shades of yellow, characteristic of betaxantins and betalamic acid.

Extreme acidic $\mathrm{pH}$ (2.4) and basic (8.0) conditions and the heating time of five minutes was sufficient to degrade the color of betalains. At pH 5.0, it was observed higher stability of the parameter a* to 10 minutes of heating.

At 10 minutes of heating the color of betalains was stable in the range of $\mathrm{pH} 3.7$ to 5.5. After this time period, the color of betalains was degraded to orange and to yellow.

Therefore, the betalains of pitaya showed good stability in a wide $\mathrm{pH}$ range (3.0-7.0) and resistance to heating for 10 minutes at $100^{\circ} \mathrm{C}$ at $\mathrm{pH}$ 


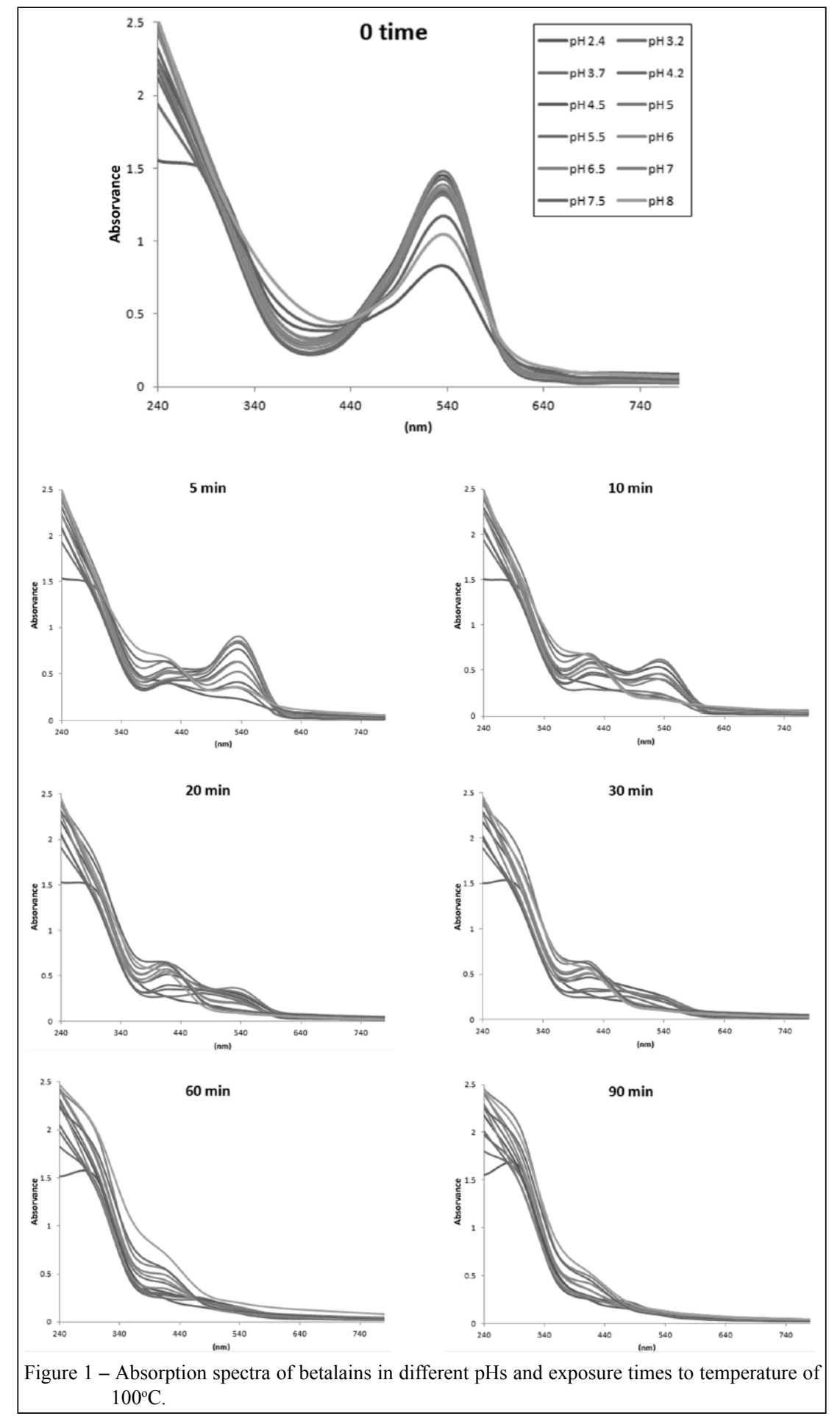

range of 3.7 to 5.5 . These results are very similar to those obtained for VAILLANT et al. (2005).

\section{CONCLUSION}

Pitaya peel can be considered as a potential source of betalains, which besides having effect as natural colorant, is rich in phenolic compounds and further presented high antioxidant activity. The betalains from pitaya peel remained stable over a wide $\mathrm{pH}$ range (3.2-7.0) and were resistant to heating $\left(100^{\circ} \mathrm{C}\right)$.up to 10 minutes at $\mathrm{pH}$ range from 3.7 to 5.5 . This feature allows the application of pitaya peel in

Ciência Rural, v.45, n.2, fev, 2015. 


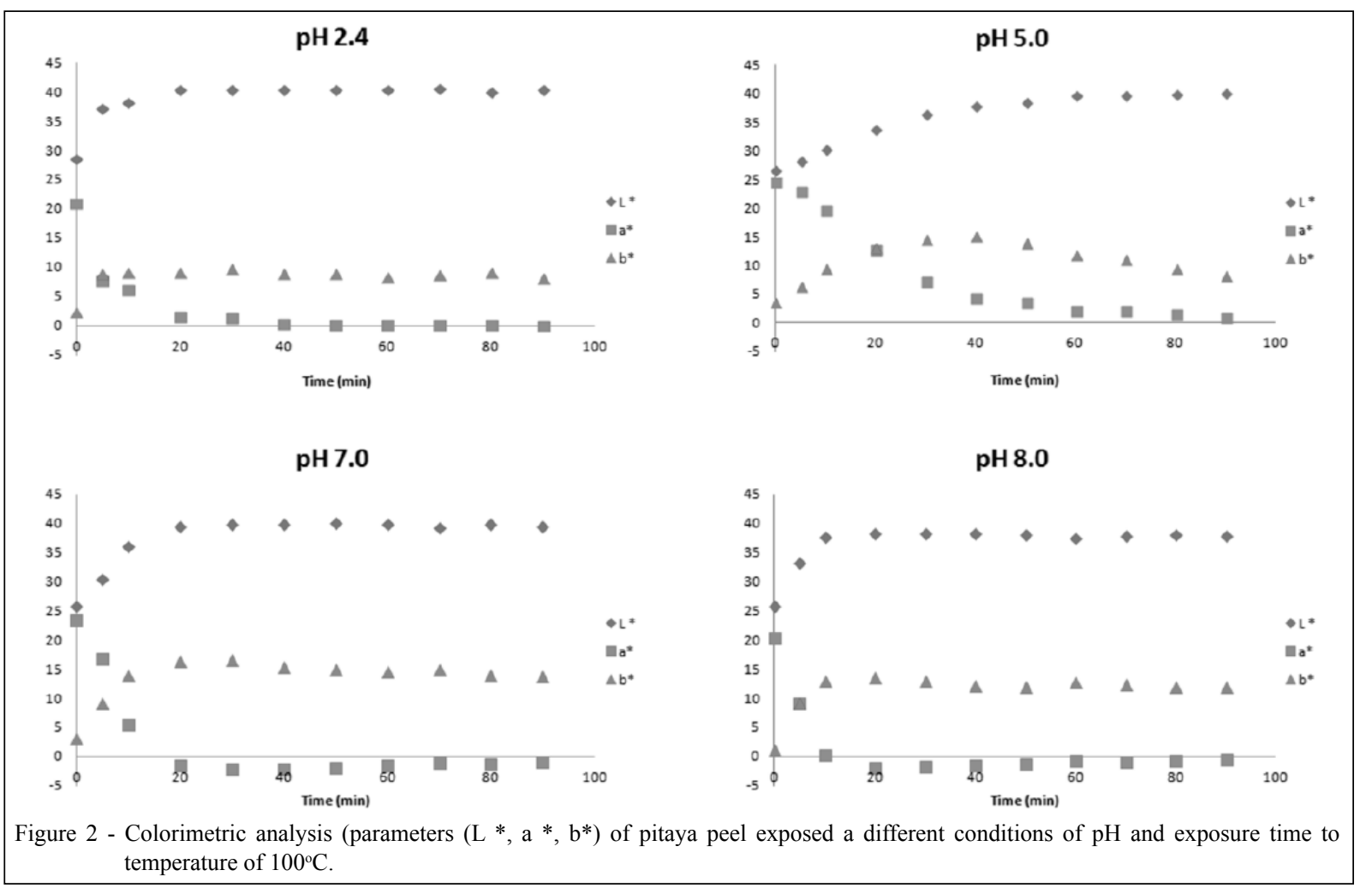

low acidity foods with moderate heat treatment, or else to be added in food after heating.

The production of natural colorant from pitaya peel can be a great alternative for the food industry, as well as reduce the environmental impact caused by the current discarding of the peel. Furthermore pitaya peel can be a healthy substitute for synthetic colorant.

\section{ACKNOWLEDGEMENTS}

The authors are grateful to Embrapa Cerrado for provide the pitaya samples and technical information and to Dr Nilton Tadeu Vilela Junqueira for providing scientific information on the pitaya fruit.

\section{REFERENCES}

BENZIE, I.F.F.; STRAIN, J.J. The ferric reducing ability of plasma (FRAP) as a measure of antioxidant power: the FRAP assay. Analytical Biochemistry, v.239, p.70-76, 1996. Avaliable from: $<$ http://www.ncbi.nlm.nih.gov/pubmed/8660627>. Accessed: Jun. 7, 2012. doi: 10.1006/abio.1996.0292.

BRAND-WILLIAMS, W. et al. Use of free radical method to evaluate antioxidant activity. Lebensmittel - Wissenschaft und -Technologie. v.22, p.25-30, 1995. Avaliable from: <http://www. researchgate.net/publication/223633796>. Accessed: Sep. 14, 2012. doi: 10.1016/S0023-6438(95)80008-5.

CASTELLAR, M.R. et al. Color properties and stability of betacyanins from Opuntia fruits. Journal of Agricultural and
Food Chemistry. v.51, p.2772-2776, 2003. Avaliable from: $<$ http://pubs.acs.org/doi/abs/10.1021/jf021045h $>$. Accessed: Oct. 15, 2012. dói: $10.1021 / \mathrm{jf021045h}$.

CASTELLAR, M.R. et al. The isolation and properties of a concentrated red-purple betacyanin food colourant from Opuntiastrictafruits. Journal of the Science of Food and Agriculture. v.86, p.122-128, 2006. Avaliable from: <http:// onlinelibrary.wiley.com/doi/10.1002/jsfa.2285/abstract $>$. Accessed: Nov. 9, 2012. dói: 10.1002/jsfa.2285.

CHOO, W.S.; YONG, W.K. Antioxidant properties of two species of Hylocereus fruits. Advances in Applied Science Research, v.2, p.418-425, 2001. Avaliable from: <http://pelagiaresearchlibrary. com/advances-in-applied-science/vol2-iss3/AASR-2011-2-3-418425.pdf>. Accessed: Set. 12, 2013.

ESQUIVEL, P. et al. Phenolic compound profiles and their corresponding antioxidante capacity of purple pitaya (Hylocereus sp.) genotypes. Zeitschrift für Naturforschung, v.62, p.636-644, 2007. Avaliable from: <http://www.znaturforsch.com/ac/v62c/ s62c0636.pdf>. Accessed: jan. 10, 2014.

HERBACH, K.M. et al. Thermal degradation of betacyanins in juices from purple pitaya (Hylocereuspolyrhizus [Weber] Britton and Rose) monitored by high performance liquid chromatographytandem mass spectrometric analyses. European Food Research and Technology, v.219, p.377-385, 2004. Avaliable from: <http:// www.researchgate.net/publication/226418364>. Accessed: Jul. 21, 2013. doi: 10.1007/s00217-004-0948-8.

HERBACH, K M. et al. Betalain stability and degradation structural and chromatic aspects. Journal of FoodScience. v.71, p.41-50, 2006a. Avaliable from: <http://onlinelibrary.wiley.com/ 
doi/10.1111/j.1750-3841.2006.00022.x/abstract $>$. Accessed: May 17, 2013. doi: 10.1111/j.1750-3841.2006.00022.x

HERBACH, K.M. et al. Stability and color changes of thermally treated betanin, phyllocactin, and hylocerenin solutions. Journal of Agricultural and Food Chemistry, v.54, p.390-398, 2006b. Avaliable from: <http://pubs.acs.org/doi/abs/10.1021/jf051854b > Accessed: Nov 8, 2012. doi: 10.1021/jf051854b.

JAMILAH, B. et al. Physico-chemical characteristics of red pitaya (Hylocereuspolyrhizus) peel. International Food Research Journal, v.18, p.279-286, 2011. Avaliable from: <http://www.ifrj. upm.edu.my/18\%20(01)\%202011/(28)\%20IFRJ-2010-060\%20 Jamilah\%20UPM[1].pdf>. Accessed: Apr 26, .2013.

KIM, D.O. et al. Vitamina C equivalente antioxidantcapacity (VCEAC) of phenolics phytochemicals. Journal of Agricultural and Food Chemistry. v.50, p.3713-3717, 2002. Avaliable from: $<$ http://www.ncbi.nlm.nih.gov/pubmed/12059148>. Accessed: Jul. 12, 2013. doi: 12059148

LAKO, J. et al. Phytochemical flavanols, carotenoids and the antioxidant properties of a wide selection of Fijian fruit, vegetable and other readily available foods. Food Chemistry, v.101, p.17271741, 2007. Avaliable from: <http://repository.usp.ac.fj/749/>. Accessed: Oct. 15, 2012.

LI-CHEN, W. et al. Antioxidant and antiproliferative activities of red pitaya. Food Chemistry. v.95, p.319-327, 2006. Avaliable from: $\quad<$ http://www.researchgate.net/publication/248510478 Antioxidant_and_antiproliferative_actvities_of_red_pitaya $>$. Accessed: Jan. 13, 2014. doi: 10.1016/j.

MIZRAHI, Y. et al. Cacti as crops. Horticultural Review, v.18, p.291-320, 1997. Avaliable from: <http://onlinelibrary.wiley.com/ doi/10.1002/9780470650608.ch6/summary>. Accessed: May. 10, 2013. doi: 10.1002/9780470650608.ch6.

MOBHAMMER, M.R. et al. Colour studies on fruit juice blends from Opuntiaand Hylocereuscacti and betalain-containing model solutions derived therefrom. Food Research International, v.38, p.975-981, 2005. Avaliable from: <http://www.hugedrive. com/published/WG/show.php?q=U0VBQ1VDS1RIT1JO 9cbc5d61\&file= $=\mathrm{NDE}=>$. Accessed: Jul. 4, 2013.

MUÑOZ, D.C. et al. Los alimentos y sus nutrientes. Tablas de valor nutritivo de alimentos. México: McGraw Hill Interamericana, 2002. 203p.

PANTELIDIS, G.E. et al. Antioxidant capacity, phenol, anthocyanin and ascorbic acid contents in raspberries, blackberries, red currants, gooseberries and cornelian cherries. Food Chemistry, v.102, p.777-783, 2007. Avaliable from: <http://www.deepdyve.com/lp/ elsevier/antioxidant-capacity-phenol-anthocyanin-and-ascorbicacid-contents-in-Ow6IubFska $>$. Accessed: Nov. 13, 2013. doi: 10.1016/j.foodchem.2006.06.021

ROSSI, J.A.J.; SINGLETON, V.L. Colorimetry of total phenolics with phosphomolybdic phosphotungstic acid reagents. American
Journal of Enology and Viticulture, v.16, p.144-158, 1965. Avaliable from:: <http://ajevonline.org/content/16/3/144.short>. Accessed: Set. 28, 2013.

STINTZING, F.C. et al. Evaluation of colour properties and chemical quality parameters of cactus juices. European Food Research and Technology. v.216, p.303-311, 2003. Avaliable from: <http://www.researchgate.net/publication/226207032>. Accessed: Apr. 16, 2013. doi: 10.1007/s00217-002-0657-0.

STINTZING, F.C.; CARLE, R. Functional properties of anthocyanins and betalains in plants, food, and in human nutrition. Trendsin Food Science and Technology. v.15, p.19-38, 2004. Avaliable from: <http://www.deepdyve.com/lp/elsevier/ functional-properties-of-anthocyanins-and-betalains-in-plantsfood-and-S4QE6MnvEL>. Accessed: Nov. 7, 2013.

STINTZING, F.C. et al. Structural investigations on betacyanin pigments by LC NMR and 2D NMR spectroscopy, Phytochemistry. v.65, p.415-422, 2004. Avaliable from: <http:// www.researchgate.net/publication/8888335>. Accessed: Sep. 22, 2013. doi: $10.1016 /$ j.

STINTZING, F.C. et al. Color, betalainpattern, andantioxidantpropertiesofcactus pear (Opuntiassp.) clones. Journal of Agricultural and Food Chemistry, v.53, p.442-451, 2005. Avaliable from: <http://pubs.acs.org/doi/abs/10.1021/ jf048751y>. Accessed: Dec. 10, 2013. doi: 10.1021/jf048751y.

SCHLIEMANN, W. et al. The decisive step in betaxanthin biosynthesis is a spontaneous reaction. Plant Physiology. v.119, p.1217-1232, 1999. Avaliable from: <http://www.plantphysiol. org/content/119/4/1217.abstract>. Accessed: Dec. 9, 2013. doi: 10.1104/pp.119.4.1217.

TANG, C.S.; NORZIAH, M.H. Stability of betacyanin pigments from red purple pitaya fruit (Hylocereuspolyrhizus): influence of $\mathrm{pH}$, temperature, metal ions and ascorbic acid. Indonesian Journal of Chemistry. v.7, p.327-331, 2007. Avaliable from: <http:// pdm-mipa.ugm.ac.id/ojs/index.php/ijc/article/viewArticle/446>. Accessed: Mar. 12, 2013

VAILLANT, F. et al. Colourant and antioxidant properties of redpurple pitahaya (Hylocereus sp.) Fruits. v.60, p.1-10, 2005. Avaliable from: <http://journals.cambridge.org/download.php?file $=\% 2$ FFRU $\% 2$ FFRU60 01\%2FS0248129405000071a.pdf\&code $=$ 3d8a07f5d470f771533e-435a6523a1b7>. Accessed: Feb. 25, 2013. doi: $10.1051 /$ fruits:2005007.

WU, L. et al.Antioxidant and antiproliferative activities of red pitaya. Food Chemistry, v.95, p.219-327, 2006. Avaliable from: <http:// www.sciencedirect.com/science/article/pii/S0308814605000889>. Accessed: May 2, 2013. doi: 10.1016/j.foodchem.2005.01.002.

ZHIJIAN, D.; XIN, Y. Studies on the stability of red pigment in Hylocereusundatus fruit. Jounal of South China Agricultural University, v.24, p.79-83, 2003. Avaliable from: <http:// agris.fao.org/agris-search/search.do?f=2004/CN/CN04032. xml;CN2004080789>. Accessed: Nov. 30, 2012. 